\title{
PERAN ORANG TUA, SEKOLAH DAN MASYARAKAT DALAM MEMBANGUN MASYARAKAT KEWARGAAN (CIVIL SOCIETY) DI SMA NEGERI 4 KUPANG
}

\author{
Efraim Semuel Nalle \\ Universitas Nusa Cendana \\ efraimnalle@yahoo.co.id
}

\begin{abstract}
Abstrak
Penelitian ini dilatarbelakangi oleh semakin banyaknya penyimpanganpenyimpangan dalam masyarakat yang secara langsung maupun tidak langsung mempengaruhi karakteristik masyarakat itu sendiri. Hasilnya, apa yang masyarakat lihat, alami dan rasakan, memberikan pengaruh terhadap perkembangan masyarakat, baik pengaruh positif maupun negatif. Karena itu, diperlukan modal kajian masyarakat kewaragaan (Civil Society) sebagai tolok ukur dalam membangun masyarakat. Penelitian kualitatif dengan metode fenomenologi dan budaya ini dilakukan di SMA Negeri 4 Kupang. Teknik pengumpulan data menggunakan observasi, wawancara, dan dokumnetasi. Data yang diperoleh dari informen, selanjutnya diolah dan dianalisis dengan menggunakan analisis model interaktif, hasilnya sebagai berikut : 1) Kurang optimalnya peran orang tua dalam membangun masyarakat kewargaan (Civil Society), 2) Sekolah secara baik menanamkan konsep masyarakat pada peserta didiknya namun perlu penguatan karakter pada pesertadidik, 3) Tidak dijalankan secara baik konsep masayarakat kewargaan (Civil Society) dalam kehidupan bermasyarakat, 4) kendala yang mengakibatkan tidak terbentuknya masyarakat kewargaan (Civil Society) secara baik meliputi kurang obtimalnya pendidikan karakter, sifat ketergantungan masyarakat yang begitu tingi kepada pemerintah, kurangnnya fasilitas dalam pengembangan anak di sekolah, kurangnnya pendidikan politik dan komunikasi politik serta, dan adanya praktik nepotisme dan kepentingan dalam pelaksanaan keadilan sosial.
\end{abstract}

Kata Kunci : Orang tua, Sekolah, Masyarakat, Masyarakat Kewargaan

\begin{abstract}
The increasing of social deviation in society becomes the main background of this research where of course it directly or indirectly affects their characteristic. As the result, society's development will be negatively or positively affected by what they see, what they feel, and what they have. So, there must be a civil society inspection as the criterion to give information about the real situation of society. The method used was qualitative method with cultural and phenomenological method which was done in SMA Negeri 4 Kupang. Technique of data collection was observation, interviews and documentation. The data gained from the
\end{abstract}


informants was analyzed by interactive model, and the researcher gained some results as follows : (1) the lack of parent's role in building up the civil society; (2) school implants the concept of civil society to the students but it is necessary to reinforce students' character; (3) the concept of civil society is not operated as well as it has to be in society; (4) the constraints that caused the lack of the concept of civil society are character education that is not too optimal, the nature of dependence to the government in society which is very high, the lack of school facilities to support students' development, the lack of politic education and politic communication, and the practice of nepotism in realization of social justice.

Keyword : Parents, Schools, Society, and Civil Society.

\section{A. Pendahuluan}

Masyarakat Kewargaan atau Civil Society pada hakikatnya merupakan suatu konsep tentang keberadaan masyarakat yang mandiri dan dalam batas-batas tertentu mampu mamajukan dirinya sendiri serta cenderung membatasi campur tangan negara ke dalam realitas (kenyataan) yang telah diciptakan sebagai ruang kegiatannya (Rasyit dalam Sujatmiko, 2001;40).

Membangun masyarakat kewargaan (civil society) tidaklah mudah, diperlukan unsur-unsur yang menjadi prasyarat agar terwujudnya masyarakat ini. Unsur pokok yang harus dimiliki, yaitu meliputi ruang publik yang bebas, demokrasi, toleransi, kemajemukan, dan keadilan sosial. Dari beberapa unsur tersebut untuk mewujudkannya diperlukan lingkungan pendidikan yang baik agar terciptanya masyarakat kewargaan (civil society)

Jika peran alam keluarga (orang tua), alam perguruan (sekolah) dan alam pergerakan pemuda (masyarakat) ini dijalanakan dengan baik, maka akan terciptanya sebuah masyarakat kewargaan (civil society) di dalam negara.

Begitu pula di Indonesia. Indonesia yang merupakan negara demokrasi dengan masyarakatnya yang begitu plural, dari segi kepercayaan, budaya, dan bahasa. Dari keberagaman tersebut Indonesia memiliki tradisi kuat dalam masyarakat kewargaan (civil society) jauh sebelum negara ini berdiri. Hal ini dapat dilihat dari kiprah beragam organisasi sosial keagamaan dan pergerakan nasional dalam perjuangan merebut kemerdekaan dan dasar negara Indonesia yaitu Pancasila serta semboyan Bhinneka Tunggal Ika yang mempersatukan 
masyarakat yang begitu pluralistik menjadi satu Indonesia. Namun saat ini, mutu masyarakat kewargaan (civil society) Indonesia kian menurun, hal tersebut dapat dilihat dari Indeks Demokrasi Indonesia (IDI) 2015 yang diumumkan Badan Pusat Statistik. Memudarnya kosep masyarakat kewargaan di Indonesia pun dapat dilihat dari kecenderungan menguatnya desakan untuk menjadikan fatwa lembaga keagamaan sebagai tolok ukur kesahihan perilaku berbangsa. Fenomena ini tidak hanya ditemukan pada masyarakat awam, tetapi juga di kalangan terpelajar. Meski sifatnya tak mengikat secara yuridis, dalam banyak kasus fatwa mampu menyandera logika bernegara seperti pada kasus pengharaman pluralisme, Syiah, dan Ahmadiyah yang menjadi dasar berbangsa. Akan beda hal jika sebuah fatwa dijadikan salah satu bahan pertimbangan kebijakan (Haq; 2013;2).

Penelitian AF di 4 SMU Negeri di 4 daerah tahun 2011 menemukan, budaya kewargaan tidak jadi arus besar di institusi pendidikan. Pendidikan religiositas belum sepenuhnya masuk ke ruang-ruang konvergensi nilai-nilai kewargaan dengan nilai-nilai agama yang berdasarkan pada toleransi dan pluralisme. Pendidikan kewarganegaraan pun belum berhasil mentransformasikan prinsip kewargaan ke ranah kognisi dan konatif siswa (AF .2011;74).

Selain itu konsep masyarakat kewargaan (civil society) tingkat daerah seperti Nusa Tenggara Timur (NTT), juga mengalami penurunan, hal ini dapat dilihat dari Indeks Demokrasi Indonesia NTT Tahun 2014 yang hanya sebesar 68,81 dibandingkan dengan IDI 2013 sebesar 73,29.

Namun konsep masyarakat kewargaan (civil society) ini kurang bertumbuh dengan baik, hal ini dapat dilihat dari rasa individualis yang menggejala di kalangan warga Kota Kupang. Dengan alasan "waktu adalah uang( time is money)” akhirnya mewujudkan kepedulian warga Kota Kupang sebagai “Kota Kasih” terasa begitu mahal (Raharjo. 2006;1).

Konsep masyarakat kewargaan (civil society) yang kurang bertumbuh dengan baik di Kota Kupang juga dapat dilihat dari kurang terbukanya ruang emansipasi perempuan dalam kancah perpolitikan. Ini dilihat dari hanya satu orang saja dari kaum perempuan yang mencalonkan diri dalam ajang pemilihan walikota 2017. Hanya Yovita Anike Mitak yang mendaftar sebagai bakal calon 
walikota di tiga partai politik, yakni Gerindra, NasDem, dan PKB. Hal ini merupakan sautu kegagalan Partai politik dalam memproduksi pemimpin feminis atau kader politik dari kaum perempuan.

Selain itu, aspek yang juga mempengaruhi kurang berkembangnnya masyarakat kewargaan (civil society), yaitu orang tua dan sekolah. Hasil penelitian Sontasi $(2012 ; 100)$ peran orang tua dalam menanamkan nilai-nilai moral dalam keluarga di Kota Kupang belum tersusun atau terakomodir dengan baik dilihat dari aspek religius, aspek sosial, aspek ekonomi, aspek keteladanan, dan aspek dasar-dasar Pancasila..

Selain itu orang tua di Kota Kupang masih suka menanamkan pengaruh kepada anak-anaknya untuk menjadi seorang pegawai negeri sipil (PNS) yang mengakibatkan tingkat ketergantungan masyarakat meningkat kepada pemerintah. Ha ini berlangsung sampai di tingkat pendidikan formal, sekolah tidak mampu merubah pola pikir lulusannya untuk mencari pekerjaan di sektor swasta sehingga untuk menjadi seorang PNS menjadi pilihan utama.

Bukan hanya itu saja permasalahan di Kota Kupang, masalah mengenai kenakalan remaja yang semakin tidak terkendali seperti dimuat dalam NTT Terkini yang memeberitakan terjadi tawuran antar Sekolah Menengah Atas (SMA) Negeri 3 Kupang dengan Sekolah Menegah Kejuruan (SMK) Negeri 2 Kupang yang terjadi pada 2 Februari 2013 di depan Kantor Sistem Atministrasi Manunggal Satu Atap (SAMSAT) Kupang. Juga tawuran antara SMA Negeri 4 Kupang dengan SMK Negeri 1 Kupang yang terjadi pada 15 Agustus 2013 di depan Universitas Nusa Cendana. Selain itu sebanyak 53,8 \% remaja di Kota Kupang, pernah mengalami Kekerasan Berbasis Gender dan Seksualitas (KBGS). Sepanjang tahun 2016 terdapat sebanyak 142 kasus atau 53 persen kasus KBGS dan sebanyak 83 kasus atau 31,4 \% untuk kasus pemakasaan berhubungan seksual

Masalah- masalah diatas merupakan masalah kewargaan (civil society) yang kompleks sehingga butuh pemecahan agar tercipta masyarakat yang mandiri dan dalam batas-batas tertentu mampu mamajukan dirinya sendiri serta cenderung membatasi campur tangan negara ke dalam realitas (kenyataan) yang telah diciptakan sebagai ruang kegiatannya. 
Peneliti memfokuskan pada peran orang tua, sekolah dan masyarakat dengan rumusan masalah: Bagaimana peran orang tua ikut membangun pembentukan masyarakat kewargaan (civil society)?Bagaimana pembelajaran sekolah ikut mendukung peningkatan kualitas masyarakat kewargaan (civil society)? Bagaimana masyarakat melaksanakan perannya untuk mendukung pembentukan masyarakatkewargaan (civil society)? Bagaiaman kendala-kendala yang dihadapi orang tua, sekolah dan masyarakat dalam membentuk masyarakat kewargaan (civil society)? Penelitian ini bertujuan Untuk mengetahui bagaimana peran orang tua ikut membangun pembentukan masyarakat kewargaan (civil society), untuk mengeahui bagaimana pembelajaran sekolah ikut mendukung peningkatan kualitas masyarakat kewargaan (civil society), mengetahui bagaimana masyarakat melaksanakan perannya untuk mendukung pembentukan masyarakatkewargaan (civil society), mengetahui analisis kendala-kendala yang dihadapi orang tua, sekolah dan masyarakat dalam membentuk masyarakat kewargaan (civil Society).

\section{B. KAJIAN TEORI}

Masyarakat Kewargaan atau Civil Society pada hakikatnya merupakan suatu konsep tentang keberadaan masyarakat yang mandiri dan dalam batas-batas tertentu mampu mamajukan dirinya sendiri serta cenderung membatasi campur tangan negara ke dalam realitas (kenyataan) yang telah diciptakan sebagai ruang kegiatannya (Rasyit dalam Sujatmiko, 2001:40). Komponen-komponen/ factorfaktor yang menjadi prasyarat terwujudnya masyarakat ini, menurut Eisenstadt (Gafar, 2006:180) meliputi otonomi, Akses Masyarakat Terhadap Lebaga Negara, Arena Publik yang Otonom, dan Arena Publik yang Terbuka. Selain itu karakterisitik masyarakat kewargaan (civil society) juga dapat dilihat dari beberapa unsur pokok (Ubaedillah dan Rozak. 2010;185) yaitu Wilayah Publik yang Bebas dalam arti ruang publik yang bebas sebagai sarana untuk mengemukakan pendapat warga masyarakat, Demokrasi yang berarti suatu tatanan sosial politik yang bersumber dan dilakukan oleh, dari, dan untuk warga negara, Toleransi dengan maksut sikap saling menghargai dan menghormati perbedaan pendapat, Pluralisme bermakna pertalian sejati kebhinekaan dalam 
ikatan-ikatan keadaban dan Keadilan Sosial dalam pengertian adanya keseimbangan dan pembagian yang proporsional atas hak dan kewajiban setiap warga negara yang mencakup seluruh aspek kehidupan: ekonomi, politik, pengetahuan, dan kesempatan.

Mewujudkan Karakteristik/ unsur pokok di atas, diperlukan peran serta berbagai pihak, yang meliputi orang tua, sekolah, dan masyarakat. Peran orang tua yang meliputi Pendidikan Iman, Pendidikan Moral, Penddikan Fisik, Pendidikan Intelektual, Pendidikan Psikis, Pendidikan Sosial dan Pendidikan Seksual (Abdullah Nasih Ulwan dalam Hadzuka, 2014:2). Juga Peran sekolah terdiri dari Mengembangkan kecerdasan pikiran, memberikan pengetahuan, spesialisasi, efisiensi, sosialisasi, konservasi, transimisi Kultur dan penanaman ketrampilan (Suwarno dalam Hayati. 2013). Serta peran masyarakat yaitu memberikan pendidikan kepada masyarakat baik itu pendidikan kurikuler maupun non kulikuler serta peningkatan profesi, Meningkatkan kesejateraan masyarakat, Mengembangkan bakat dan minat dan Menanamkan dan meningkatkan nilai moral dan spiritual masyarakat (Ihsan. 2010). Jika peran itu dapat dijalnakan dengan baik maka bukan tidak mungkin akan terciptanya masyarakat kewargaan (civil society).

\section{METODOLOGI}

Menganalisis kajian diatas penelitian ini menggunakan pendekatan kualitatif dengan metode fenomenologi dan budaya, dimana peneliti ingin melihat bagimana orang tua dan sekolah mentransformasikan kebudayaan yang dimiliki dalam membudayakan anak, serata bagaimana masyarakat membangun masyarakat itu sendiri. Penelitian dilakukan di SMA Negeri 4 Kupang. Subjek yang di wawancarai meliputi orang tua murid yang dipilih berdasakan tingkat pendidikan, perstasi siswa, dan tingkat kenakalan siswa , kepala sekolah, wakil kepala sekola bagian kurikulum, guru PPKn, guru agama, Pembina kepramukaan, tokoh agama dan Rukun Warga (RW). Teknik pengumpulan data menggunakan observasi, wawancara, dan dokumnetasi yang diuji keabsahannya dengan metode Triangulasi sumber. Data yang diperoleh selanjutnya diolah dan dianalisis dengan menggunakan analisis model interaktif. 


\section{HASIL DAN PEMBAHASAN}

\section{Peran Orang Tua dalam Membangun Masyarakat Kewargaan}

Orang tua sebagai sumber pendidikan pertama dan suri tauladan bagi anak, memiliki peran yang sangat penting dalam membentuk kepribadian dan karakter mereka. Anak yang dipandang sebagai sebuah tabula rasa dimana orang tua berkewajiban untuk menulis atau mingisinya, baik berkaitan dengan perkembangan Bahasa, logika, nilai spiritual, nilai moral, tradisi kultur dan konatif harus dididik secara baik. Jika peran yang begitu urgen dari orang tua dapat dijalankan secara maksimal bukan tidak mungkin jika kelak Kota Kupang atau dalam lingkup yang lebih sebar yaitu Indonesia dapat terciptanya masyarakat kewargaan. Agar dapat melihat semua itu peneliti melakukan penelitian di SMA Negeri 4 Kupang untuk melihat peran orang tua dalam memberikan Pendidikan Iman, Pendidikan Moral, Penddikan Fisik, Pendidikan Intelektual, Pendidikan Psikis, Pendidikan Sosial Pendidikan Seksual untuk membangun masyarakat dapat bahas sebagai berikut (Abdullah Nasih Ulwan dalam Hadzuka. 2014. 2).

Orang tua merupakan salah satu unsur pembentuk masyarakat kewargaan, sudah menjalankan perannya dengan membentuk karakter spiritual dan moral anak, yang meliputi bertakwah kepada Tuhan Yang Maha Esa, Jujur, disiplin, sopan, dan bertangungjawab. Hampir keseluruhannya sudah diajarkan dengan baik oleh orang tua walaupu ada beberapa hal seperti jujur dan disiplin yang perlu diperkuat lagi. Dalam membangun masyarakat kewargaan, tidak hanya mebentuk karakter spiritual dan moral anak saja tetapi juga dibutuhakn unsur pokok yang harus dipenuhi, untuk membentuk karakterisitk masyarakat kewargaan yang meliputi Otonomi, Demokrasi, toleran, pluralisme dan berkeadilan sosial (Ubaedillah dan Rozak. 2010: 128) yang secera komperhensif dapat di deskripsikan sebagai berikut;

Pertama dalam hal otonomi; otonom ini sendiri bermakna masyarakat mandiri dimana mereka mempunyai posisi yang sama untuk melakukan transaksi sosial dan politik. Bertalian dengan itu orang tua sudah memainkan peranannya dengan mengajarkan anak-anak nya untuk mandiri baik sengaja maupun tidak sengaja, seperti anak mereka dapat mengerjakan pekerjaan-pekerjaan rumah yang meliputi memasak, mencuci, menyapu, menstrika, dan dapat mengerjakan tugas 
dari sekolah sendiri. Dari sisi lain anak-anak sekarang sangatlah komunikatif dan berani tampil didepan umum, hal ini didukung dari pengakuan informen yang mengatakan bahwa anak-anak mereka sering mengisi liturgi gereja dengan bernyanyi, mereka juga bisa menjadi pemimpin ibadat atau MC, dan anak-anak juga sering mempresentasi hasil pekerjaan mereka didepan kelas. Dalam membangun masyarakat kewargaan, tidaklah cukup untuk dikatakan anak sudah mencapai kemandiran yang kewargaan. Orang tua lupa bahwa anak tidak selamanya bergantung kepada mereka, orang tua harus juga mengajarkan bagaiaman anak dapat mandiri secara finansial, bukan berarti mangajarkan anak untuk berbisnis namun untuk menanamkan jiwa wirausaha sejak dini.

Kedua, demokrasi. Demokrasi disini menganut konsep dari, oleh dan untuk rakyat. Dalam hal peran orang tua dalam membangun demokrasi banyak orang tua yang menganut dari orang tua, oleh orang tua dan untuk anak. Orang tua tidak memberikan kesempatan untuk anak menyampaikan pendapat mereka, apa yang mereka inginkan dan apa yang mereka perlukan. Orang tua lebih bersikap otoriter dalam hal mengambil keputusan keluarga. Dalam konsep membangun masyarakat yang demokratis, orang tua harus bisa memberikan kesempatan dan dukungan kepada anak, dengan menganut konsep dari anak, oleh anak dan untuk anak.

Ketiga Toleransi. Konsep dari toleransi disini yaitu bagaimana dalam masyarakat ada saling menghormati dan menghargai. Peran orang tua pada bagian ini telah dijalankan secara baik hal ini ditunjukan dengan pengakuan orang tua, yang mengatakan bahwa mereka mengajarkan bagaimana harus mengharagai dan menghormati sesama baik itu yang berbeda agama, suku dan ras. Ajaran ini pula diterima baik oleh anak-anak mereka, dibuktikan dengan pengakuan orang tua yang mengatakan bahwa anak-anak mereka mengucapkan selamat kepada temanteman mereka saat hari raya keagamaan masing-masing.

Keempat Pluralisme. Konsep dari plurasilme ini mengenai perbedaan yang memiliki kebaikan budi pekerti. Peran orang tua pada bagia ini sudah dilaksanakan dengan baik, karena orang tua sadar dalam kehidupan ini setiap orang mempunyai perbedaan, baik itu perbedaan suku, agama, dan ras. Orang tua selalu mengajarkan kepada anak untuk selalu menghargai dan menghormati 
orang, mereka mengajarkan bagaiman cara berpicara kepada orang yang lebih tua, bagaiman harus bersikap sopan santun, dan bagaiman harus menghargai dan menghormati keyakinan orang lain.

Kelima Keadilan Sosial. Konsep ini bermakna bahwa hak dan kewajiban haruslah dibagi secara seimbang yang proporsional. Peran orang tua dalam hal ini sudah dilakukan seperti pengakuan dari orangtua yang mengakatakan bahwa mereka tidak membedakan mana yang anak angkat dan mana yang anak kandung, orang tua juga selalu meberikan uang jajan yang sama banyak kepada semua anaknya, jika mereka membeli pakaian maka akan membelikan kepada semua anaknya dan jika ada kue atau makanan harus dibagi sama rata. Namun praktik keadilan disini tidaklah proporsional, orang tua lebih banyak menganut konsep keadilan komutatif dimana sesuatu dianggap adil apabila dibagi sama rata. Hal ini yang membuat rasa keadilan pada anak hanya sebatas sama rata sama rasa.

Dari deskripsi unsur pokok pembentukan karekteristik masyarakat kewargaan diatas, dapat dilihat bahwa orang tua sudah mendidikan rasa toleransi dan pluralisme dengan baik, namun mereka belum mampu dalam mendidik anak untuk otonom, demokrasi dan berkeadilan sosial.

\section{Peran Sekolah dalam Meningkatkan Kualitas Masyarakat Kewargaan}

Sekolah merupakan tempat kedua setelah orang tua dalam mendidik anak. Sekolah tidak hanya memberikan pengetahuan saja tetapi juga memberikan pendidikan spiritual, moral dan ketrampilan hal diajarkan agar anak didik yang di hasilkan tidak hanya memiliki pengetahuan dan ketrampilan yang yang baik saja namun juga memiliki karakter yang baik pula. Senada dengan itu, konsep masyarakat kewargaan juga menuntut agar masyarakat memiliki sikap, pengetahuan dan ketrampilan yang baik dan ke tiga kompetensi tersebut dijabarkan dalam karakteristik masyarakat kewargaan, seperti otonomi, demokrasi, toleransi, pluralism dan keadilan sosial.

Untuk mendukung terciptanya karakteristik masyarakat kewargaan yang didasari pada peran sekolah yang meliputi mengembangkan kecerdasan pikiran dan memberikan pengetahuan, spesialisasi, efisiensi, sosialisasi dan konservasi serta transimisi Kultur,Penanaman Ketrampilan (Suwarno dalam Hayati. 2013. 161), sekolah telah mendidik sikap spiritual dan sikap sosial. Menurut hasil 
wawancara, observasi dan dokumentasi pendidikan karakter di sekolah ini belum dijalankan secara maksimal dan ada guru yang tidak mau mencatat kelakukan tidak baik dari anak-anak sehingga mereka kurang mendapatkan penguatan karakter. Sikap spiritual dan sikap sosial itu meliputi :

a. Bertakwah kepada Tuhan Yang Maha Esa

Dalam hal ini sekolah sudah berusaha menanamkan nilai ini sesuai dengan visi, misi dan tujuan sekolah melalui mata pelajaran pendidikan agama, PPKn, dan pembinaan iman yang dilakukan setiap hari sabtu. Pendidikan ini perlu lebih di perdalam lagi karena berdasarkan hasil observasi ditemukan hampir setengah dari siswa, saat berdoa mereka tidak melaksanakannya dengan khusyuk.

b. Jujur

Dalam hal kejujuran sekolah sudah mengajarkan secara baik, namun masih ada kekurangan pada bagian kejujuran dalam mengerjakan tugas atau ujian, berdasarkan observasi hampir sebagain siswa berlaku curang dalam mengerjakan tugas ataupun ujian

c. Disiplin

Karakter disiplin sangatlah penting dalam membangun manusia yang sukses dalam hal ini sekolah sudah berusaha menanamkan kedisiplinan ini namun berdasarkan hasil wawancara kedisiplinan dalam sekolah ini sudah menurun dan perlu ada penegakan aturan hal ini dapat dilihat dari pengakuan informen yang mengaku siswa d isini sering terlambat masuk sekolah ataupun masuk kelas saat selesai istirahat. Persoalan ini juga didukung dari hasil observsi yang menemukan anak kurang disiplin dalam hal pulang tepat waktu dan diperkuat lagi dari hasil dokumentasi yang menunjukan sebagian besar pelanggaran yang dibuat oleh siswa adalah alpa, tidak kumpul tugas/atau tidak kerja tugas dan bolos.

d. Bertangung jawab.

Dalam hal sekolah sudah berusaha menanamkannya secara baik, hal ini dapat dilihat dari pengakuan informen bahwa anak bertanggung jawab dalam hal tugas yang diberikan kepadanya tetapi ada beberapa anak yang memang tidak bertanggung jawab. Bertolak belakang dari pengakuan informen hasil observasi dan dokumentasi menyatakan bahwa anak masih kurang bertanggunga jawab hal 
ini dapat dilihat dari anak suka menghindari kewajiban dan tidak mengerjakan tugas yang diberikan.

Sekolah telah mendidik dan mempraktikan dengan baik agar siswa memiliki karakter otonom, demokrasi, toleransi, plurasilme dan keadilan sosial, namun sekolah perlu penguatan dalam hal pendidikan spiritual dan pendidikan moral. Seperti bertakwa kepada Tuhan yang Maha Esa, disiplin, jujur dan bertanggung jawab. Senada dengan pendidikan karakter yang kurang di SMS Negeri 4 Kupang.

\section{Peran Masyarakat dalam Mendukung Pembentukan Masyarakat Kewargaan}

Pembentukan masyarakat kewargaan yang didasari peran masyarakat, yang meliputi Memberikan pendidikan, Meningkatkan kesejateraan masyarakat, Mengembangkan bakat dan minat dan Menanamkan dan meningkatkan nilai moral dan spiritual masyarakat (Ihsan 2011. 59). Diawali dengan penanaman nilai moral dan nilai spiritual pendidikan aqidah, sekolah minggu yang dilakukan pada hari minggu dan hari rabu, pendidikan katekasasi, penguatan iman dan moral juga dikumandangakan saat beribadat di rumah ibadat. Nilai spiritual dan nilai moral masyarakat menurut sebagian besar tokoh masyarakat mengatakan sudah baik namun ada beberapa nilai moral dan nilai spiritual yang perlu di perhatikan khusus seperti masih ada terjadi kerusuhan/perkelahian, dan masyarakat masih suka minum minuman keras secara berlebihan, juga ada beberapa tokoh masyarakat yang mengatakan bahwa nilai spiritual dan nila moral telah menjadi nomor terakhir dalam hidup.

Pembentukan/ penanaman nilai spiritual dan moral masyarakat merupakan langkah awal dalam membangun masyarakat kewargaan. Selanjutnya unsur pokok yang harus dipenuhi untuk membentuk karakteristik masyarakat kewargaan yang meliputi Otonomi, Demokrasi, toleran, pluralisme dan berkeadilan sosial (Ubaedillah dan Rozak. 2010: 128) yang secera komperhensif dapat di deskripsikan sebagai berikut:

a. Otonomi

Otonomi di sini mangandung arti masyarakat dapat mandiri juga mempunyai posisi yang sama dalam melakukan transaksi sosial maupun politik. Dalam 
pelaksanaannya para tokoh masyarakat sudah memfasilitasi mereka untuk dapat mandiri dalam hal transaksi sosial maupun politik dengan memberikan dukungan berupa fasilitas dan bantuan berupa tempat berjualan, modal usaha, alat bekerja seperti perahu yang lengkap dengan alat tangkapnyas, juga dalam bidang politik tokoh masyarakat memberikan penguatan agar masyarakat mau berpartisipasi secara bebas dalam kanca perpolitikan baik berupa mendata masyarakat, memberikan kesempatan seluas-luasnya kepada masyarakat untuk berpendapat secara bebas, namun harapan agar masyarakat bisa menjadi otonom tidak tercipta secara penuh. Yang melatarbelakangi hal ini karena ada masyarakat yang mendapat bantuan alat, mereka tidak merawat alat tersebut, jika alat itu rusak mereka langsung mejualnya, dalam hal politik masyarakat cenderung diam, masa bodoh dan tidak mendengar. Hal itu terjadi karena masyarakat menganggap hidup dari dulu sampai sekarang sama saja.

b. Demokrasi

Demokrasi juga diajarkan kepada masyarakat, bagaimana harus menghargai perbedaan dalam berdemokrasi, harus memilih pemimpin yang seperti apa dan para tokoh masyarakat juga berusaha mengajak masyarakat untuk menggunakan hak pilihnya. Menurut mereka demokrasi di Kota Kupang masih 40 \% berjalan, stiker demokrasi memang sudah ada namun stiker tersebut di tempelkan pada bodi yang salah, hal ini diakibatkan karena pendidikan politik yang kurang dari partai politik, jika ada pun hanya sebatas di kaderisasi dalam rangka persiapan pemilihan, dalam hal komunikasi politk juga masih kurang karena komunikasi politik itu dilakukan hanya pada saat akan dilakukannnya pemilihan. Masih adanya KTP ganda, pemilih orang mati, terdapat pemilih anak kecil yang dibawah umur serta masih menyebarnya konsep asal bapak senang yang membuat para pemimpin tidak mau mendengar/melihat kesalahan-kesalahan mereka yang disampaikan oleh masyarakat.

c. Toleransi

Toleransi dalam masyarakat, lebih dari setengah tokoh masyarakat mengatakan baik, hal ini dapat dilihat dari adanya pertukaran mimbar antara gereja katolik dan gereja protestan, adanya kerjasama antara Kristen dan islam dalam menjaga keamanan saat hari raya besar keagamaan, adanya pahaman "untuk mu agama mu 
untuku agama ku”, adanya kerjasama antar warga untuk membantu warga yang mendapat musibah seperti kematian yang tidak memandang suku, agama dan ras. Ada bebebrapa dari tokoh masyarakat mengatakan bahwa toleransi ini hanya kamuflase, masyarakat hanya tidak ingin membuat rusuh saja sehingga mereka memilih diam dan tidak berbuat apa-apa tetapi didalam hati mereka ada rasa tidak suka.

d. Pluralisme

Konsep dari pluralisme ini mengenai perbedaan yang memiliki kebaikan budi pekerti. Dalam masyarakat Kota Kupang kebaragaman sangatlah besar yang meliputi keberagaman agama, suku dan ras. Walaupun keberagaman itu besar, menurut tokoh masyarakat mereka selalu membangun budi pekerti yang baik kepada masyarakat agar selalu saling menghargai dan menghormati sesama.

e. Keadilan Sosial

Keadilan sosial merupakan hal yang penting, karena dengan keadilan sosial baik, maka kesejahteraan masyarakat akan terjamin. Dalam hal kesejahteraan masyarakat. para tokoh masyarakat seperti RW membantu masyarakat dengan mendata masyarakat yang tidak mampu dan membuat proposal kepada pemerintah agar mereka dapat dibantu dan hasilnya menurut pengakuan para RW wilayah mereka mendapat banyak bantuan seperti raskin, bantuan langsung tunai, bantuan dana pemberdayaan ekonomi masyarakat (PEM), beasiswa, dan bedah rumah. Di wilayah pesisir pantai masyarakat mendapat bantuan berupa koperasi, bantuan tenda-tenda jualan, dan bantuan kapal beserta alat tangkap ikan.

Lain pihak dalam meningkatkan kesejahteraan masyarakat para tokoh agama melalui tempat ibadat yang mereka pimpin membantu dalam bentuk pemberian zakat kepada fakir miskin pertahun, pemberian dana pengembangan jemaat berupa pinjaman tanpa bunga kepada penjual sayur, pemberian diakonia kepada janda, duda, dan anak yatim piatu. Menjadi masalah dalam praktiknya menurut pengakuan sebagian tokoh masyarakat belum terjadi keadilan sosial. Hal ini dapat dilihat masih adanya praktik siapa yang dekat maka dia yang lebih di perhatikan, dan masih adanya praktik pilih kasih (pilih saudara, pilih kepentingan). 
Dari deskripsi unsur pokok pembentukan karekteristik masyarakat kewargaan diatas, dapat dilihat masyarakat sudah menanamkan toleransi dan pluralisme dengan baik namun unsur pokok otonomi, demokrasi dan keadilan sosial belum dijalankan dengan baik sehinga tidak terciptanya masyarakat kewargaan. Hal ini juga didukung oleh Suroto (2015; 664) yang menyatakan, Pertama. Karakteristik masyarakat Indonesia antaranya adalah: (1) Pluralistik/keberagaman, (2) sikap saling pengertian antara sesama anggota masyarakat, (3) toleransi yang tinggi dan (4) memiliki sanksi moral. Kedua. Hambatan sekaligus tantangan dalam mewujudkan masyarakat madani model Indonesia, yaitu : (a) semakin berkembangnya orang “miskin” dan orang yang merasa miskin, (b) LSM dan partai politik muncul bagaikan jamur yang tumbuh di musim penghujan sehingga memungkinkan berbagai “ketidakjelasan”, (c) pers berkembang pesat dan semakin canggih tetapi justru "fesimisme” masyarakat yang terjadi, (d) kaum cendikiawan semakin banyak tetapi cenderung berorientasi pada kekuasaan, (e) kurang pede untuk bersaing dan senantiasa merasa rendah diri. Ketiga. Tantangan yang harus dihadapi oleh masyarakat Indonesia ke depan adalah (1) sikap demokratis, (2) sikap toleran, (3) saling pengertian, (4) berakhlak tinggi, beriman dan bertaqwa, (5) berwawasan global.

Hal ini diperkuat kembali oleh hasil penelitian Fajar (2010;1) yang menyatakan pelaksanaan peran partai politik tidak disertai oleh pelaksanaan fungsi parti politik sebagai Instrumen of Political Education dengan baik dan benar.

\section{Kendala-Kendala dalam Membangun Masyarakat Kewargaan}

Membangun masyarakat kewargaan tidaklah mudah, hal ini dapat dilihat dari berbagai kendala yang dihadapi orang tua, sekolah dan masyarakat untuk membangunnya. Kendala-kendala tersebut dapat dilihat sebaga berikut :

a. Pendidikan karakter oleh sekolah yang belum maksimal sehingga terciptanya anak yang kurang bertakwa kepada Tuhan yang Maha Esa, tidak jujur, tidak disiplin, dan tidak bertanggung jawab serta cinta damai.

b. Orang tua tidak mendidik anak agar dapat mandiri secara finansial sehingga dimasa depan anak cenderung akan bergantung pada negara. 
c. Kurangnya fasilitas pendukung di sekolah sehinga menggangu pengembangan anak.

d. Masih ada orang yang berpendapat bahwa toleransi yang ada sekarang adalah toleransi kamuflase.

e. Kurangnya pembiasaan kepada anak untuk melakukan musayawarah mufakat.

f. Kurangnya komunikasi politk dan pendidikan politik kepada masyarakat.

g. Orang tua cenderung mengajarkan keadilan komutatif kepada anak.

h. Adanya praktik nepotisme dan kepentingan dalam pelaksanaan keadilan sosial.

Bertalian dengan kendala-kendala diatas AS. Hikim (Ubaedillah dan Rozak. 2010), karakter masyarakat kewargaan (Civil Society) di Indonesia masih sangat bergantung terhadap negara sehingga selalu berada pada posisi subordinat, khususnya bagi mereka yang berada pada strata sosial bawah.

Kendala selanjutnya dilihat dari Masyarakat Indonesia yang sangat pluralistik atau lebih tepat disebut masyarakat yang sangat tinggi tingkat fragmentasi sosialnya, apakah itu bersumber pada masalah ekonomi, sosial budaya, etnisitas, juga termasuk bidang politik. Itu semua merupakan sesuatu yang menghambat tumbuh dan berkembangnya civil society, atau setidaknya melambatkan perkembangannya (Gafar, 2006:187)

\section{E. KESIMPULAN DAN SARAN}

\section{Kesimpulan}

Tidak dipungkiri lagi bahwa masyarakat kewaragaan dengan karakterisitik/unsur pokok meliputi Otonomi, Demokrasi, Toleransi, Pluralisme dan Keadilan Sosial yang merupakan konsep yang ideal dalam implikasi pada terbentuknya Negara yang kuat. Masyarakat kewargaan tidak muncul dengan sendirinya, ia membutuhkan suatu sistem yang bekerja dengan baik untuk dapat membangunnya. Orang tua, sekolah dan masyarakat merupakan sistem yang paling relevan untuk dapat mewujud nyatakan masyarakat kewargaan ini.

Berdasarkan hasil kajian disimpulkan bahwa, orang tua belum menjalankan perannya secera optimal, dilihat dari unsur pokok terbentuknya 
masyarakat kewargaan. Memang dalam kriteria toleransi dan pluralisme telah diajarkan secara baik namun yang mengakibatkan tidak terbentuknya masyarakat kewargaan secara optimal di karenakan kriteria demokrasi tidak diajarkan secara baik, orang tua masih cenderung menggunakan konsep dari orang tua, oleh orang tua dan untuk anak. Dalam hal otonomi dan keadilan sosial, orang tua mengajarkan anak secara setengah-setengah, hal ini dilihat dalam hal keadilan mereka lebih banyak mengunakan keadilan komutatif dibandingkan keadilan distributif dan untuk otonomi orang tua belum mengajarkan anak untuk mandiri secara finansial.

Berbeda dengan orang tua, sekolah telah melaksanakan perannya secara baik dalam membangun masyarakat kewargaan, dilihat dari unsur pokok terbentuknya masyarakat kewargaan. Sekolah hanya butuh mengobtimalkan dalam menanamkan pendidikan karakter berupa bertakwa kepada Tuhan, jujur, disiplin dan bertanggung jawab.

Bertalian dengan orang tua dan sekolah. Peran masyarakat dalam membangun masyarakat kewargaan masih kurang. Memang dari segi toleransi dan pluralisme sangat baik. Kurang terbentuknya masyarakat kewargaan di akibatkan karena Otonomi, Demokrasi dan keadilan sosial tidak berjalan sebagaimana mestinya. Hal ini diakibatkan karena kurang mandirinya masyarakat membangun diri sehingga banyak bergantung pada bantuanbantuan yang diberikan oleh pemerintah, kurangnya komunikasi politik, kurangnya pendidikan politik, dan masih banyaknya praktik nepotisme serta kepentingan dalam masyarakat.

Tidak terbentuknya masyarakat kewargaan ini secara baik diakibatkan karena kendala-kendala, seperti kurang obtimalnya pendidikan karakter, sifat ketergantungan masyarakat yang begitu tinggi kepada pemerintah, kurangnya fasilitas dalam pengembangan anak di sekolah, kurangnya pendidikan politik dan komunikasi politik serta, adanya praktik nepotisme dan kepentingan dalam pelaksanaan keadilan sosial.

\section{Saran}

Berdasarakan kesimpulan diatas peneliti memberikan saran-saran sebagai berikut. Pertama, sekolah dan masyarakat harus bekerja sama dalam 
menanamkan nilai spiritual dan nilai moral anak yang semakin menurun. Orang tua juga hendaknya mendukung apa yang dilakukan sekolah dalam mendidik anak.

Kedua, pemerintah dan partai politik harus menjalankan fungsi dan tugasnya dalam memberikan komunikasi politik dan pendidikan politik yang berkelanjutan.

Ketiga. Pemerintah harus menegakan aturan yang sudah ada secara tegas atau merumuskan aturan yang baru dalam hal pemberantasan praktik nepotisme dalam masyarakat

Keempat. Pemerintah harus memberikan pelatihan ketrampilan secara berkelanjutan dengan sistem evaluasi dan kotrol yang baik kepada masyarakat yang kurang mampu agar mereka dapat hidup mandiri.

Kelima. Pemerintah harus mengadakan sosialisasi kepada masyarakat mengenai pentingnya mendidik anak menjadi mandiri secara finansial.

\section{DAFTAR PUSTAKA}

Adha Muhammad M dan Kesuma Febra A. 2010. Penguasaan Konsep Pembelajaran Pendidikan Kewarganegaraan Untuk Meningkatkan Sikap Nasionalisme Siswa. Jurnal Civicus. Vol. 15 No. II Juni.

AF Ahmad Gaus. 2013. Pemetaan Problem Radikalisme di SMU Negeri di 4 Daerah. Jurnal Maarif vol 8 No 1 Juli..

Amin, Maswardi. M. 2015. Pendidikan Karakter Anak Bangsa Edisi 2. Yogyakarta : Calpulis

Badudu, J, S. Zain S, M. 2001. Kamus Umum Bahasa Indonesia. Jakarta: Pustaka Sinar Harapan.

Berita Resmi Statistik Nasional No. 73/08/Th. XIX, 03 Agustus 2016.

Berita Resmi Statistik NTT No. 15/08/53/Th. XVIII, 13 Agustus 2015.

Ceka Ardita dan Murati Rabije. 2016. The Role of Parents in the Education of Children. Journal of Education and Practice Vol.7, No.5. Faculty of Philosophy, University of Tetova, 176 no.53A, Tetovo,1200 Macedonia, Faculty of Philosophy, University of Tetova,1200 Macedonia. 
Fagbeminiyi. Fasina, F. 2011. The Role of Parents in Early Childhood Education: A Cas Study of Ikeja, Lagos State, Nigeria. Journal of Human Social Science Volume 11 Issue 2 Version 1.0 March . Covenant University, Ota, Ogun State Global.

Fajar, Wildan Nurul. 2011. Model Pendidikan Kewarganegaraan Sebagai Media Pendidikan Politik bagi Kader dalam Meningkatkan Kesadaran Politik (Penelitian Grounded Theory dalam Konteks Pendidikan Kewarganegaraan di Indonesia). Jurnal Civicus. Vol. 16. No.1 Januari.

Feka, Mikhael. 2016. Perempuan dan Pilwalkot Kupang. Pos Kupang Jumat 29 April.

Gafar, Afan. 2006. Politik Indonesia: Transisi Menuju Demokrasi. Yogyakarta: Pustaka Pelajar.

Gaurav Sachar. 2015. Teacher's Positive Influence On Learner's Character Formation. International Journal of Educational Research and Technology P-ISSN 0976-4089; E-ISSN 2277-1557 IJERT: Volume 6 June hal 49-52.

Haq Fajar Riza Ul. 2013. Intoleransi di Tahun Politik. Kompas Kamis 7 Maret.

Haryanto. 2011. Pendidikan Karakter menurut Ki Hajar Dewantara. Dalam Jurnal Cakrawala Pendidikan. Edisi Khusus Dies Natalis UNY.

Hasbullah. 2006. Dasar-dasar Ilmu Pendidikan. Jakarta: Raja Gafindo Persada.

AF Ahmad Gaus. 2013. Pemetaan Problem Radikalisme di SMU Negeri di 4 Daerah. Jurnal Maarif vol 8 No 1 Juli.

Idi, Abdullah.2016. Etike Pendidikan:Keluarga, Sekolah dan Masyarakat. Jakarta: Raja Grafindo Persada.

Kusuma, Febra Anjar. 2012. Peranan Penguasaan Konsep Pembelajaran Pendidikan Kewarganegaraan Untuk Meningkatkan Sikap Nasionalisme Siswa di SMP N 1 Pagelaran Kabupaten Pringsewu Tahun Ajaran 2011/2012. Skripsi. Program Studi PKNJurusan Pendidikan Ilmu Pengetahuan Sosial Fakultas Keguruan dan Ilmu Pendidikan Universitas Lampung.

Mayasari Feri. 2013. Hubungan antara pola asuh demokratis orang tua Terhadap moralitas pada remaja. Jurnal. Fakultas Psikologi Universitas Semarang.

Miles, Mattew B dan Huberman A. Michael. 2007. Analisis Data Kualitatif. Buku Sumber Tentang Metode-Metode Baru. Jakarta: Universitas Indonesia Press.

Moleong, Lexy. J. 2007. Metodologi Penelitian Kualitatif. Bandung: Remaja Rosdakarya. 
Purwaningsih, Endang. 2010. Keluarga dalam Mewujudkan Pendidikan Nilai : Upaya Mengatasi Degradasi Nilai Moral. Jurnal Pendidikan Sosiologi dan Humaniora, Volume I No 1.

Salamor, Lisye. 2010. Peranan Keluaraga dan Sekolah dalam Pelaksanaan Pendidikan Nilai Guna Membentuk Karakter Anak. Prosiding Seminar Aktualisasi Pendidikan Karakter Bangsa. Bandung: Widya Aksara Press.

Samsuri. 2010. Transformasi Gagasan Masyarakat Kewargaan (Civil Society) Melalui Reformasi Pendidikan Kewarganegaraan di Indonesia (Studi Pengembangan Kebijakan Kewarganegaraan pada Jenjang Pendidikan Dasar dan Menengah Erah Reformasi). Disertasi. Sekolah Pasacasarjana Universitas Pendidikan Indonesia.

.2010. Model Pendidikan Kewarganegaraan untuk Membangun Kompetensi Warga Negara. Jurnal Civicus. Vol. 15 No. II Juni 2010.

Sontani, Erni. N. 2012. Studi Tentang Peran Orang Tua dalam Menanamkan Nilai-Nilai Moral dalam Keluarga di TK Pertiwi Kupang di Kelurahan Naikolan Kota Kupang. Skripsi. Program Studi Pendidikan Anak Usia Dini. FKIP UNDANA.

Sugiyono. 2010. Metode Penelitian Pendidikan (Pendekatan Kuantitatif, Kualitatif, dan R\&D). Bandung: Alfabeta.

Suroto. 2015. Konsep Masyarakat Madani Di Indonesia Dalam Masa Postmodern (Sebuah Analitis Kritis). Jurnal Pendidikan Kewarganegaraaan. PPKN, FKIP, Universitas Lambung Mangkurat, Banjarmasin

Ubaedillah A, Rozak Abdul(Ed). 2010. Pendidikan Kewargaan (Civic Education): Demokrasi, Hak Asasi Manusai dan Masyarakat Madani edisi ke-Tiga. ICCI UIN: Jakarta.

Westergard Elsa . 2013. Teacher Competencies and Parental Cooperation. International Journal about Parents in Education. Vol. 7, No. 2, 91-99. University of Stavanger Stavanger, Norway.

William G. Thompson . 2002. The Effects of Character Education on Student Behavior. Dissertation. the faculty of the Department of Educational Leadership and Policy Analysis East Tennessee State University. 
